\title{
Studi Eksposisi Pola Asuh Orang Tua Terhadap Anak Berdasarkan Ulangan 6:4-9
}

\author{
Ferry Simanjuntak ${ }^{\mathrm{a}}$, Henry Kurniawan ${ }^{\mathrm{b}}$
}

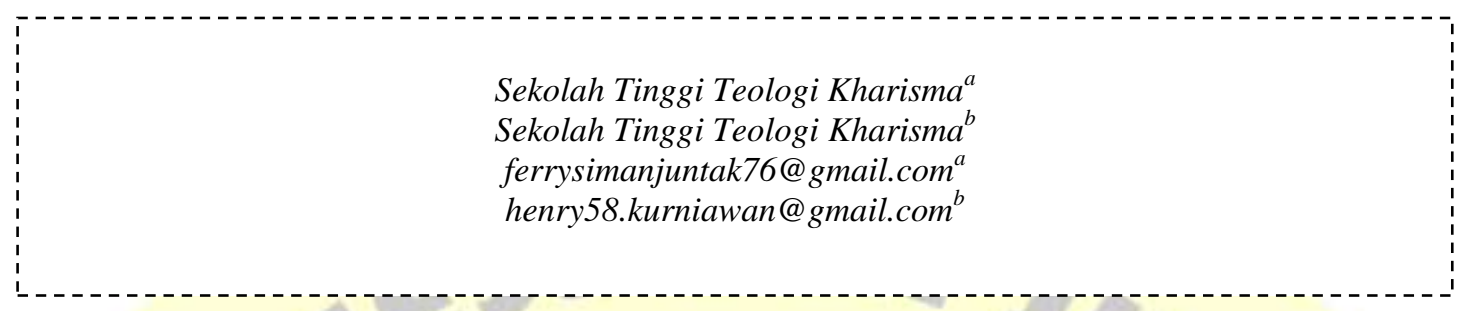

\begin{abstract}
Abstrak
Fenomena yang dapat dijumpai dalam pengasuhan anak di dalam keluarga adalah adanya "mata rantai" pengasuhan yang buruk dari generasi ke generasi, yang disebabkan karena orang tua gagal dalam mengasuh dan mendidik anak. Penelitian yang digunakan dalam penulisan ini adalah metode kualitatif studi pustaka menemukan adanya "mata rantai" tujuh kesenjangan yang terjadi pada pengasuhan anak yang menyebabkan kegagalan orang tua dalam mengasuh dan mendidik anak. Kemudian melalui studi eksposisi berdasarkan Ulangan 6:4-9 yang mengandung prinsip pengasuhan alkitabiah, ditemukan bahwa "mata rantai" tujuh kesenjangan pengasuhan orang tua itu disebabkan karena orang tua tidak hidup dengan komitmen rohani.
\end{abstract}

Kata kunci : Pola asuh, orang tua, anak, komitmen rohani.

\section{PENDAHULUAN}

Warren Stanley Heath (2016:33) mengatakan bahwa masyarakat menghadapi bermacam-macam masalah, seperti: kenakalan anak-anak, kerenggangan hubungan suami isteri, perselisihan kakak adik, depresi, ancaman bunuh diri, kehamilan anak gadis, penyalahgunaan narkotika. Hampir masalah-masalah itu berkaitan dengan kegagalan proses pendidikan anak (Heath, 2016:33). Dengan kata lain, orang tua gagal dalam mengasuh / mendidik anak. Pengasuhan buruk itu sendiri, tentunya tidak terjadi dengan serta merta, tetapi ada hal yang melatarbelakanginya. Penulis mengindikasi ada tujuh kesenjangan pada pola pengasuhan keluarga yang menjadi seperti suatu "mata rantai" yang kemudian menyebabkan terjadinya pola pengasuhan yang buruk dalam keluarga yang cenderung diteruskan dari generasi ke generasi. Tujuh kesenjangan pola pengasuhan itu dapat digambarkan sebagai berikut:

Orang tua tidak hadir/tidak berperan di tengah keluarganya sehingga terjadi pembiaran dan pengabaian oleh orang tua dalam pengasuhan anak. Survei nasional yang dilakukan oleh Komisi Perlindungan Anak Indonesia (KPAI) tentang "Kualitas Pengasuhan Anak Indonesia 2015." Hasilnya adalah peran ayah yang semakin pudar, sementara itu peran ibu masih sangat dominan dalam semua indikator yang diukur. Dalam survei itu dikatakan juga bahwa hal yang menjadi faktor penyebab anak-anak semakin kurang kasih sayang dan perhatian dari ayahnya adalah tuntutan ekonomi, kurangnya kesiapan menjadi ayah, kuatnya budaya penyerahan pengasuhan anak kepada 
ibu, serta kuatnya dikotomi (pembagian atas dua kelompok yang saling bertentangan) antara peran ayah dan ibu, membuat para calon ayah (orang tua) enggan belajar tentang cara pengasuhan dan perawatan anak, apalagi terlibat dalam pengasuhan anak. Ayah juga lebih sibuk memenuhi kebutuhan ekonomi dan lupa bahwa anak tidak hanya butuh uang dari ayah atau ibu (Prabowo, 2017).

Sementara itu berkaitan dengan pola pengasuhan dalam Ulangan 6:4-9, Jarot Wijanarko, mengatakan bahwa pengasuhan anak seperti yang diajarkan Alkitab melalui Ulangan 6:4-9 adalah bahwa pengasuhan itu merupakan tanggung jawab orang tua, bukan sekolah, pemerintah, atau gereja (Wijanarko, 2016:53). Karena itu, ketika peran ayah/orang tua dalam pengasuhan anak semakin berkurang atau memudar, itu dapat membawa dampak terjadinya kesenjangan pengajaran orang tua kepada anak, dimana pengajaran dari orang tua yang baik dan sehat tidak tersampaikan kepada anak, karena kehadiran dan peran orang tua tidak ada di tengah keluarga. Mengenai kesenjangan pengajaran orang tua terhadap anak yang terjadi dalam pengasuhan di tengah keluarga, ada suatu peristiwa yang dicatat dalam Alkitab dan dapat dijadikan sebagai contoh dan pelajaran, yaitu kisah tentang Samuel yang didapati terlalu sibuk mengurus umat Israel, sehingga pengajaran kepada anak-anaknya tidak tersampaikan. Alkitab menuliskan bahwa dari tahun ke tahun Samuel berkeliling ke Betel, Gilgal dan Mispa dan memerintah atas orang Israel di tempat-tempat itu, kemudian kembali lagi ke Rama, tempat Samuel tinggal. Namun demikian, sementara di Rama pun, Samuel masih mengurus orang-orang Israel, bukan mengurus keluarga dan anak-anaknya. Sehingga di kemudian hari, anak-anak Samuel menjadi rusak karena orang tua sibuk hingga mengorbankan atau mengabaikan waktu untuk keluarga, sehingga pengajaran dan pengasuhan yang perlu disampaikan pada anak menjadi tidak tersampaikan (Wijanarko, 2011:11).

Berkaitan dengan terjadinya kesenjangan pengajaran orang tua kepada anak, Gary Thomas mengatakan bahwa pengasuhan orang tua di Ulangan 6 adalah menekankan tentang membesarkan anak-anak yang akan mengasihi Tuhan dan menaati firman-Nya. Orang tua dipanggil untuk merawat dan membesarkan anak-anak untuk kemuliaan Tuhan (Thomas, 2017:17).

Selain itu, pelajaran lain yang bisa didapatkan dari kisah kegagalan Samuel dalam mengajar atau mengasuh anaknya adalah bahwa hal yang menyebabkan pengajaran atau pengasuhan dari Samuel sebagai orang tua tidak tersampaikan kepada anak-anaknya disebabkan karena adanya prioritas yang salah, dimana Samuel lebih memprioritaskan pada pelayanannya terhadap umat Israel hingga mengabaikan pengajaran/pengasuhan terhadap anak-anak dan keluarganya. Dengan kata lain, kesenjangan/kegagalan dalam pengajaran orang tua itu disebabkan oleh karena orang tua salah menata prioritas, baik bagi dirinya sendiri maupun bagi pengasuhan anak. Hal ini sebagaimana fenomena yang penulis dapatkan melalui survei awal untuk menemukan masalah yang terjadi, dengan menggunakan instrumen angket google form yang dimulai dari tanggal 20 Februari sampai 25 Maret 2020. Angket tersebut disebarkan kepada responden yang adalah para hamba Tuhan, karyawan swasta, ibu 
rumah tangga, fulltimer, guru, dan pelayan jemaat di Bandung. Angket disebarkan kepada delapan puluh responden, dan yang merespon ada 46 responden, tetapi yang mengisi sesuai dengan apa yang ada di angket ada 40 responden, dengan rata-rata berumur 48 tahun. Adapun pertanyaan yang penulis ajukan adalah: Apa yang menjadi prioritas pertama dari orang tua saudara, yang dahulu lakukan dalam mempersiapkan hari depan saudara sebagai anak?"

Berikut ini adalah hasil yang di dapatkan:
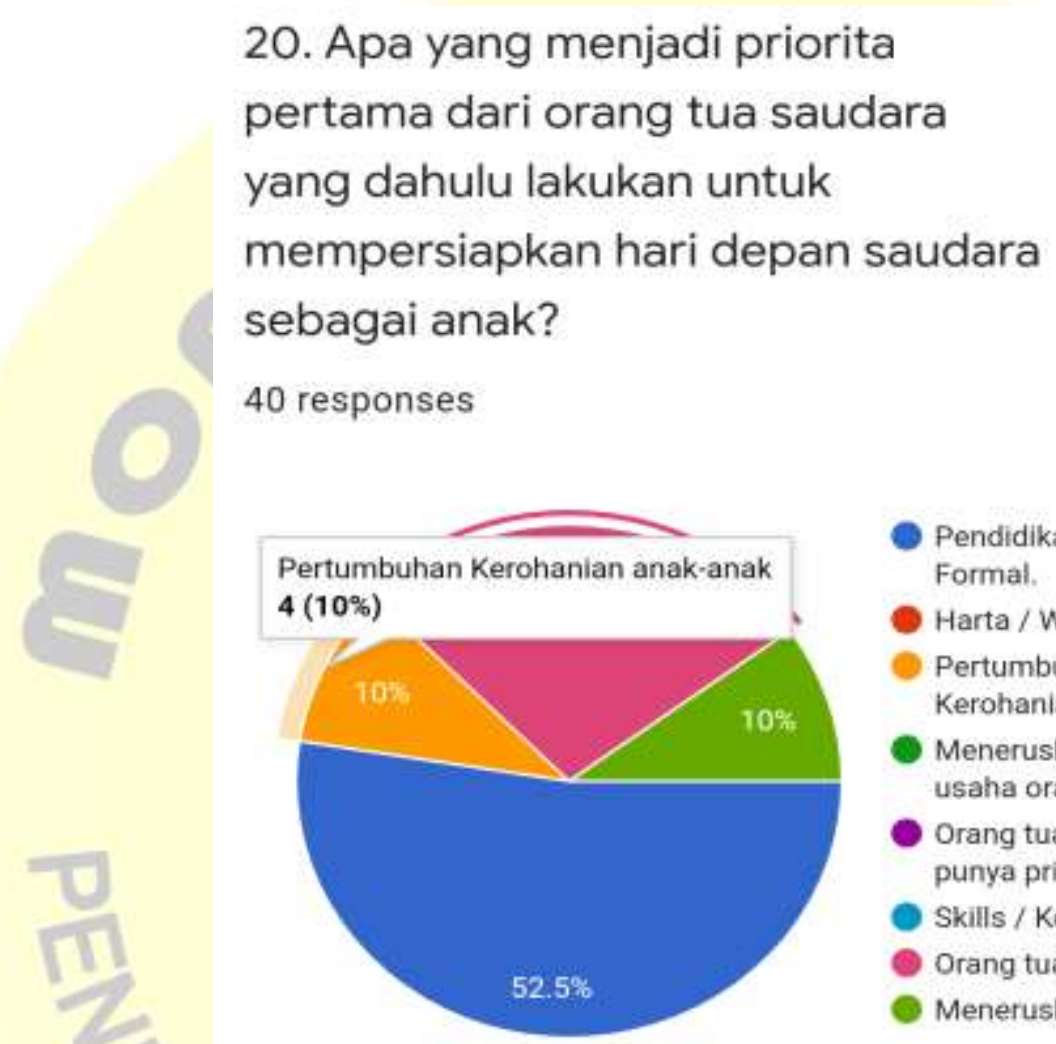

Pendidikan

Formal.

Harta / Warisan

Pertumbuhan Kerohanian anak..

Meneruskan usaha orang tua.

Orang tua tidak punya prioritas u..

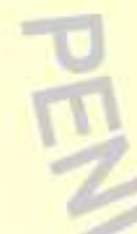

Skills / Keahlian.

Orang tua Tidak.

Meneruskan usa.

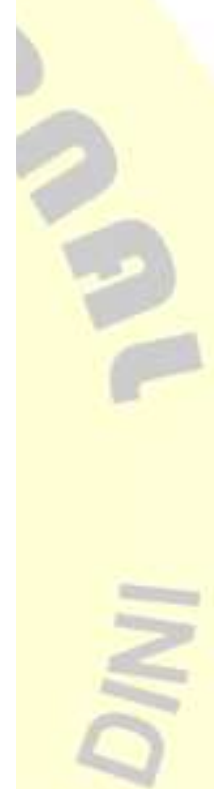

Dari tabel di atas dapat diketahui bahwa prioritas orang tua dahulu dalam mempersiapkan hari depan anak adalah: Kesatu, pendidikan formal (52,5\%). Kedua, tidak punya prioritas/memberi kebebasan kepada anak (27,5\%). Ketiga, meneruskan usaha orang tua dan pertumbuhan rohani anak (10\%). Jadi dengan demikian, dapat diketahui bahwa prioritas pengasuhan orang tua dahulu dalam pemenuhan kebutuhan akan pertumbuhan dan kesejahteraan rohani anak masih rendah/kurang.

Sementara itu, Alkitab memaparkan suatu model pendidikan/pengajaran yang di sebut dengan shema Israel (Ul. 6:4-9), yaitu pembentukan iman dan karakter setiap anak dalam konteks keluarga. Orang tua di Israel harus melaksanakan tugas dan tanggung jawab agar: Kesatu, anak-anak mampu mengenal, beribadah, dan taat kepada Allah pencipta langit dan bumi (Heath, 2016:23). Kedua, siap untuk menikah dan mendirikan rumah tangga sendiri. Ketiga, mengembangkan keterampilan bekerja untuk dapat mencukupi keperluan rumah tangganya. Anak-anak belajar di tengah keluarga, menyaksikan sendiri peran serta Allah dalam urusan sehari-hari. Hal-hal itu merupakan tujuan global pendidikan pada sepanjang zaman, yaitu relasi manusia dengan Tuhan diutamakan secara khusus, anak-anak harus belajar mengenal Allah dan 
mengalami pengalaman pribadi dengan Allah dalam setiap peristiwa yang dialami, sehingga dapat melihat peranan Allah dalam setiap peristiwa itu. Karena itu, tidak salah bahwasanya dalam melaksanakan pola pendidikan/pengajaran anak, para orang tua belajar dari bangsa Israel, karena tugas pendidikan/pengasuhan yang terkandung dalam shema tersebut adalah mandat atau perintah Tuhan yang ditujukan kepada para orang tua (Heath, 2016:29-33).

Sebagaimana prioritas ditetapkan, maka itu mempengaruhi apa yang dikerjakan. Karena itu, prioritas yang salah dapat menghasilkan perilaku yang salah/menyimpang. Berkaitan dengan terjadinya kesenjangan pada perilaku orang tua, Jarot Wijanarko dalam bukunya "Pemulihan Orang tua-Anak," menuliskan mengenai bagaimana perilaku orang tua dan bagaimana reaksi anak terhadap perilaku itu (2000:19-21).

\begin{tabular}{|c|c|c|}
\hline No. & Perilaku orang tua & Reaksi/Respon anak \\
\hline 1. & Tidak menepati janji & Hati terluka \\
\hline 2. & Tidak mengaku salah & $\begin{array}{l}\text { Kehilangan kepercayaan terhadap } \\
\text { kepemimpinan orang tua }\end{array}$ \\
\hline 3. & Menolak untuk meminta maaf & $\begin{array}{l}\text { Bereaksi terhadap kesombongan } \\
\text { orang tua, Kehilangan figur teladan }\end{array}$ \\
\hline 4. & Tidak memiliki urutan prioritas & $\begin{array}{l}\text { Merasa ayah terlalu sibuk buat } \\
\text { anaknya, anak mengikuti jadi } \\
\text { serabutan }\end{array}$ \\
\hline 5 & Mendisiplin terlalu keras & Hancur hati \\
\hline 6. & Mendisiplin dengan kemarahan & $\begin{array}{l}\text { Mememendam benih kekecewaan } \\
\text { dan kepahitan }\end{array}$ \\
\hline 7. & Mendelegasikan pendidikan & $\begin{array}{l}\text { Tidak menghargai orang tua sebagai } \\
\text { figur/guru }\end{array}$ \\
\hline 8. & Memberi kebebasan berlebih & $\begin{array}{ll}\text { Melihat } & \text { kebebasan } \\
\text { penolakan dan kebagai } \\
\text { orang tua }\end{array}$ \\
\hline 9. & Tidak menghormati orang tua & $\begin{array}{l}\text { Anak tidak menghormati kakek dan } \\
\text { neneknya }\end{array}$ \\
\hline 10. & Mengirim orang tua ke panti jompo & $\begin{array}{l}\text { Anak akan menolak orang-orang } \\
\text { yang lebih tua/kurang ajar }\end{array}$ \\
\hline 11. & Suami tidak mengasihi istri & $\begin{array}{l}\text { Anak melawan ibunya, anak } \\
\text { kecewa/kepahitan dengan ayahnya }\end{array}$ \\
\hline 12. & Istri memberontak suami & $\begin{array}{l}\text { Anak melawan ayahnya, anak } \\
\text { kehilangan figur, } \\
\text { kecewa/kepahitan dengan ibunya }\end{array}$ \\
\hline 13. & Menolak firman Tuhan & $\begin{array}{l}\text { Hal yang sama dilakukan anak, } \\
\text { tidak bisa takut akan Tuhan, }\end{array}$ \\
\hline
\end{tabular}




\begin{tabular}{|c|c|c|}
\hline & & cenderung nakal, susah dididik \\
\hline 14. & Selalu memuji anak lain & Merasa tertolak, minder, rendah diri \\
\hline 15. & Terlalu diam & $\begin{array}{l}\text { Mencari penerimaan diri dari } \\
\text { teman-teman }\end{array}$ \\
\hline 16. & Tidak konsisten standar kehidupan & Menjauh dari orang tua \\
\hline 17. & Menyeleweng dalam pernikahan & $\begin{array}{l}\text { Kebencian, kehilangan figur, } \\
\text { menikah untuk keluar dari rumah }\end{array}$ \\
\hline 18. & Selalu mengingat kesalahan & $\begin{array}{l}\text { Anak justru akan melakukan lagi, } \\
\text { anak tidak belajar arti } \\
\text { pengampunan, anak merasa ditolak } \\
\text { secara pribadi }\end{array}$ \\
\hline 19. & Tidak memiliki kesaksian & Mengikuti norma dan etika dunia \\
\hline 20. & $\begin{array}{l}\text { Tidak memberikan pendidikan rohani, } \\
\text { materialis, pelit }\end{array}$ & Anak tumbuh duniawi \\
\hline 21. & Mengutamakan pekerjaan & $\begin{array}{l}\text { Membangun nilai hidup atas dasar } \\
\text { hal-hal yang sementara. }\end{array}$ \\
\hline 22. & Mengancam & Membenci, memberontak \\
\hline 23. & Menekan, menyalahkan & $\begin{array}{l}\text { Menekan dan menyalahkan adik- } \\
\text { adiknya } \\
\text { penyaluran/pelampiasan }\end{array}$ \\
\hline 24. & Memanjakan & Liar \\
\hline 25 & Tidak memperhatikan anak & $\begin{array}{l}\text { Mencari perhatian dengan nakal, } \\
\text { usil, aktif, dan berbagai kegiatan } \\
\text { ekstrim }\end{array}$ \\
\hline
\end{tabular}

Dari tabel di atas dapat diketahui bahwa perubahan/kesenjangan perilaku pada orang tua, membawa dampak pada kekacauan hidup anak-anaknya. Sebagai contoh adalah ketika orang tua tidak memiliki urutan prioritas, maka yang terjadi adalah anak merasa ayah terlalu sibuk hingga tidak ada waktu buat anaknya, sehingga perilaku anak mengikuti jadi serabutan. Ketika orang tua tidak memperhatikan anak, maka anak mencari perhatian dengan nakal, usil, aktif, dan berbagai kegiatan ekstrim. Ketika orang tua terlalu memanjakan anak, maka anak bertumbuh menjadi liar atau sulit diatur/diarahkan. Ketika orang tua tidak memberikan pendidikan rohani, materialis, pelit, maka anak bertumbuh menjadi duniawi.

Mengenai adanya dampak yang terjadi terhadap anak akibat dari kesenjangan perilaku orang tua, Stanley Heath mengatakan bahwa kekacauan hidup anak merupakan buah dari pola hidup kedua orang tuanya. James Dobson, seorang psikiater dan konselor yang terkenal, sebagaimana dikutip oleh Stanley Heath, mengatakan bahwa pusat konseling James Dobson telah melayani lebih dari 5.000 kasus kenakalan anak. Penuntasan suatu kasus setiap kali tercapai setelah orang tua dari anak tersebut rela 
untuk mengubah sikapnya. Kenakalan remaja merupakan hasil dan ujian mutu pola pendidikan yang diterapkan orang tua sepanjang anak itu di bawah usia remaja. Jikalau relasi timbal balik anak dan orang tua sudah rusak pada waktu kecil, anak tidak bersedia mengikuti petunjuk orang tuanya lagi (Heath, 2016:138).

Yang kemudian dapat dikatakan adalah bahwa kesenjangan pada perilaku orang tua dalam mengasuh anak membawa dampak pada kerusakan/kekacauan perilaku anak, sehingga hal ini mengindikasikan adanya ketidaktuntasan orang tua dalam membentuk dan membangun kerohanian, kepribadian, dan pola hidup anak. Stanley Heath mengungkapkan bahwa kasus-kasus dalam konseling yang ditangani oleh para pendeta dan psikolog adalah merupakan hasil dari kegagalan orang tua dalam melakukan pemenuhan kebutuhan anak pada masa kecil. Pola pelaksanaan konseling itu ialah mengungkapkan tugas-tugas yang seharusnya sudah diselesaikan oleh orang tua, tetapi yang terjadi adalah orang tua mengabaikan tugas atau tidak menuntaskan tugas pengasuhan anak, sehingga pada saat anak tersebut telah berkeluarga (menjadi suami atau menjadi isteri), maka ketidaktuntasan pembentukan rohani, kepribadian, dan pola hidup anak membawa dampak pada ketidaksiapan menjadi orang tua (Heath, 2016: 127).

Membahas tentang menuntaskan tugas pengasuhan anak, Edwin Charis dalam bukunya "Smart Parenting" mengatakan tentang pentingnya suatu prinsip alkitabiah dalam pola pengasuhan orang tua terhadap anak, dimana itu merupakan suatu pola pengasuhan universal, yang akan memperlengkapi orang tua dalam menjalankan pengasuhan di tengah keluarga. Prinsip alkitabiah dalam pola pengasuhan yang universal itu adalah sebagaimana yang dimaksudkan dalam Ulangan 6:4-9, dimana Tuhan memberikan perintah kepada orang tua untuk berperan aktif mengajar, mengasuh, mendidik, dan menjadi teladan bagi anak-anak (Charis, 2016:140-145).

Namun demikian, walaupun dalam keadaan tidak siap menjadi orang tua, kehidupan rumah tangga dan pengasuhan terhadap anak tetap berjalan. Ketika terjadi ketidaksiapan dalam mengasuh anak, maka hal yang paling mudah dilakukan adalah meniru bagaimana cara orang tuanya dulu mengasuh anak-anak. Dalam survei yang sama, penulis mengajukan pertanyaan: Faktor apa/siapa yang paling mempengaruhi dalam cara saudara mengasuh anak?" Berikut hasil jawaban yang diperoleh dari 39 responden yang valid, yaitu bahwa faktor yang paling mempengaruhi responden sebagai orang tua masa kini di dalam mengasuh anak adalah: Kesatu, faktor orangtua sebelumnya, yaitu sebesar $71,8 \%$. Kedua, faktor lingkungan, yaitu sebesar $17,9 \%$. Ketiga, faktor media elektronik, yaitu sebesar 5,1\%. 

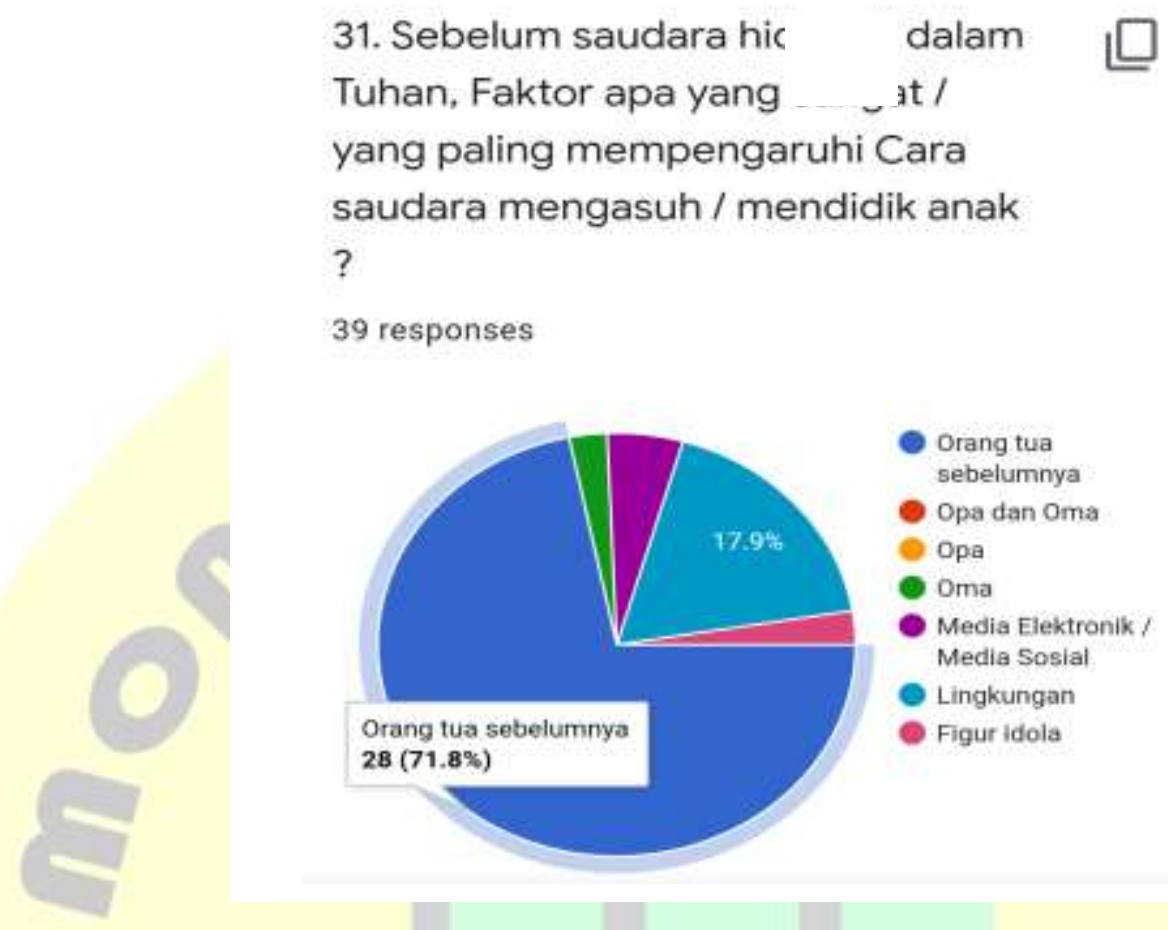

Berdasarkan uraian di atas, maka penulis akan mengkaji lebih lanjut penulisan ini melalui penelitian dengan judul, "Studi Eksposisi Berdasarkan Ulangan 6:4-9 Tentang Pola Asuh Orang tua Dan Relevansinya Bagi Orang tua Masa Kini”. Melalui tulisan ini, penulis merumuskan mengenai bagaimana orang tua masa kini dapat menjembatani kesenjangan-kesenjangan pengasuhan yang terjadi pada orang tua dahulu dengan generasi selanjutnya, sehingga "mata rantai" pengasuhan yang buruk itu tidak diteruskan dari generasi ke generasi. Penulis juga berharap agar tulisan ini dapat memberikan kepada orang tua prinsip-prinsip pengasuhan yang alkitabiah sehingga dapat digunakan sebagai arahan atau tuntunan untuk penerapan praktis pengasuhan di tengah keluarga, sehingga orang tua untuk dapat mengarahkan diri pada tujuan utama dari tugasnya, yaitu menghasilkan anak-anak yang benar dan ilahi bagi Tuhan, artinya bahwa anak-anak mempunyai hubungan yang benar dengan Tuhan, selaras dengan kehendak Tuhan, dan mencerminkan sifat-sifat Tuhan. Dengan demikian dapat terjadi pemulihan dalam hal kualitas pola asuh dan kualitas kehidupan di dalam keluarga dan melahirkan generasi-generasi yang takut akan Tuhan, yang mengasihi dan menghormati Tuhan, dan yang hidup berpusat kepada Tuhan. Pada akhirnya, menjadi suatu warisan rohani, dan inspirasi bagi generasi selanjutnya yang akan menjadi orang tua.

\section{METODE}

Metode yang penulis gunakan untuk melaksanakan penelitian ini adalah metode kualitatif, deskriptif, studi pustaka, dimana teks/nats kitab Ulangan 6:4-9 menjadi dasar pengkajian penulisan ini, untuk mendapatkan prinsip-prinsip pengasuhan yang 
alkitabiah serta dapat dipakai sebagai pedoman dan landasan dalam melakukan pengasuhan anak. Dalam studi kepustakaan ini, penulis menggunakan Alkitab sebagai sumber dan otoritas yang utama untuk mendapatkan data yang valid dan dapat memahami mengenai pokok yang diteliti, karena Alkitab adalah firman Allah sebagai sumber kebenaran yang absolut dan yang telah teruji. Sedangkan melalui studi eksposisi ini, penulis hendak meneliti faktor yang menyebabkan terjadinya kesenjangan pada pengasuhan orang tua dahulu, dan dampaknya bagi orang tua kini, serta bagaimana orang tua kini menjembatani kesenjangan yang terjadi pada pengasuhan orang tua dahulu itu, sehingga mata rantai "warisan" pengasuhan yang buruk dari orang tua sebelumnya tidak diteruskan kepada generasi selanjutnya (Nainggolan dan Labobar, 2021:113-125).

\section{HASIL DAN PEMBAHASAN}

Memperhatikan adanya fenomena-fenomena yang terjadi di atas, dapat diketahui/ditemukan relevansi pola asuh orang tua sebelumnya bagi orang tua masa kini, yaitu bahwa dengan adanya "mata rantai" kesenjangan dalam pengasuhan orang tua dahulu, membawa dampak adanya "warisan" pola pengasuhan yang buruk dari orang tua dahulu terhadap pola pengasuhan orang tua masa kini.

Adapun dampak dari "warisan" pola pengasuhan yang buruk dari orang tua dahulu terhadap pola pengasuhan orang tua masa kini berdasarkan uraian di atas dapat dirangkum sebagai berikut: pola pengasuhan yang buruk dari orang tua dahulu berdampak pada terjadinya penyimpangan perilaku pada anak, pola pengasuhan yang buruk dari orang tua dahulu berdampak pada terjadinya kesenjangan (ketidaktahuan atau kebingungan) dalam mengasuh anak pada orang tua masa kini, pola pengasuhan yang buruk dari orang tua dahulu berdampak pada terjadinya berbagai macam masalah dalam keluarga, pola pengasuhan yang buruk dari orang tua dahulu berdampak pada pengajaran orang tua terhadap anak tidak tersampaikan, pola pengasuhan yang buruk dari orang tua dahulu berdampak pada terjadinya ketidaktuntasan orang tua dahulu dalam membangun kerohanian, kepribadian dan pola hidup anak sehingga di kemudian hari terjadi ketidaksiapan menjadi orang tua, sehingga karena adanya ketidaktahuan, kebingungan, serta ketidaksiapan menjadi orang tua, maka cara yang paling mudah bagi orang tua masa kini mengasuh anak adalah dengan cara meniru orang tua sebelumnya. Karena meniru pola pengasuhan yang buruk dari orang tua sebelumnya, maka dapat dimungkinkan bahwa pengasuhan orang tua kini kepada generasi selanjutnya juga mengalami kesenjangan yang serupa, yang pada akhirnya jika tidak ada upaya perbaikan atau pemulihan, maka dapat membentuk mata rantai pola pengasuhan yang buruk kepada generasi-generasi selanjutnya.

Berikut adalah kajian melalui studi eksposisi mengenai prinsip pengasuhan yang alkitabiah yang dapat dipakai sebagai pedoman dan landasan bagi pengasuhan yang universal. 


\section{Landasan Alkitab Mengenai Pola Asuh}

Dasar firman Tuhan tentang pola asuh orang tua menurut Ulangan 6:4-9 sebagaimana dinyatakan dalam Alkitab penuntun hidup berkelimpahan adalah bahwa (APHB, 2010: 285) bagian ini sering kali disebut sebagai "Shema" dan sangat dikenal orang Yahudi pada zaman Yesus karena diucapkan setiap hari oleh orang Yahudi yang saleh dan secara tetap dalam kebaktian di sinagoge. Shema ini merupakan pernyataan terbaik tentang kodrat monoteistis Allah. Pernyataan Shema ini diikuti perintah ganda kepada bangsa Israel, yaitu untuk mengasihi Allah dengan segenap hati, jiwa, dan kekuatan (ay. 5-6), serta untuk mengajarkan iman orang tua dengan tekun kepada anakanak (ay. 7-9), (APHB, 2010: 285).

Dalam Ulangan 6:6 dituliskan bahwa apa yang Tuhan perintahkan Itu haruslah diperhatikan. Hal ini memberi pesan bahwa Allah benar-benar menginginkan firman Tuhan itu tersimpan dalam hati umat-Nya. Sebagaimana Rasul Paulus juga menyatakannya dalam Kolose 3:16 agar supaya perkataan Kristus diam dengan segala kekayaannya diantara orang-orang percaya. Hal ini hanya dapat dicapai dengan terus menerus mempelajari Alkitab. Kemudian dalam Ulangan 6:7 Tuhan memerintahkan kepada orang tua agar mengajarkan firman Tuhan kepada anak-anak dengan berulangulang. Hal ini memberi pesan bahwa salah satu cara utama orang tua mengungkapkan kasih kepada Allah (Ul. 6:5), ialah dengan mempedulikan kesejahteraan rohani anakanak dan berusaha menuntun anak-anak kepada hubungan yang setia dengan Tuhan. Mengajarkan berulang-ulang kepada anak-anak memberi pesan bahwa pembinaan rohani anak-anak seharusnya menjadi perhatian utama semua orang tua, dimana pengarahan rohani harus berpusat di rumah, melibatkan ayah dan ibu. Tujuan dari pengarahan oleh orang tua ialah mengajar anak-anak untuk takut akan Tuhan, berjalan di jalan Tuhan, mengasihi dan menghargai Tuhan, melayani Tuhan dengan segenap hati dan jiwa. Serta, orang tua harus dengan tekun dan berulang-ulang memberikan kepada anak-anaknya pendidikan yang berpusatkan Allah, dimana segala sesuatu dihubungkan dengan Tuhan dan jalan-jalan Tuhan (APHB, 2010: 285).

Dengan demikian, berdasarkan uraian di atas, dapat diketahui bahwa Ulangan 6:4-9 berisikan perintah/mandat dari Tuhan kepada orang tua untuk melaksanakan pengasuhan dan pendidikan kepada anak-anaknya, suatu pengasuhan dan pendidikan yang berpusatkan kepada Tuhan, yang dimulai dari rumah/keluarga. Karena itu, perintah dalam Ulangan 6:4-9 ini sangat relevan dengan pengasuhan orang tua kepada anak sampai kini. Setiap orang tua yang percaya Alkitab adalah firman Tuhan, niscaya menerima mandat Tuhan ini, sekalipun tertulis di dalamnya bahwa perintah/mandat ini ditujukan kepada umat Israel.

Demikian pula Stanley Heath, mengatakan bahwa Shema ini bukanlah perintah khusus yang hanya ditujukan kepada umat Israel. Shema ini berlaku juga sebagai perintah bagi para orang tua masa kini. Hal ini berdasarkan pada kebenaran bahwa Tuhan Yesus juga menyampaikan pengajaran dan perintah shema semasa pelayananNya di bumi ini. Suatu perintah untuk mengasihi Tuhan dengan segenap hati, dengan segenap jiwa, dan dengan segenap akal budi (Mat. 22:37, Mrk. 12:30, Luk. 10:27). Jadi 
dalam prakteknya, hal-hal yang dipelajari dan diterima oleh anak-anak harus didasarkan pada firman Tuhan (Heath, 2016:31-32).

\section{Konteks Dekat}

Pembahasan konteks dekat yang berhubungan dengan Ulangan 6:4-9 adalah Ulangan 5:1. Penulis menyertakan terjemahan Ulangan 5:1 dari versi King James sebagai berikut: Dan Musa memanggil seluruh Israel, dan berkata kepada mereka, Dengarlah, hai Israel, ketetapan dan keputusan yang Aku ucapkan di telingamu hari ini, agar kamu dapat mempelajarinya, dan memelihara, dan melakukannya (Alkitab Sabda).

Dalam Ulangan 5:1 terjemahan baru Lembaga Alkitab Indonesia (LAI) tidak ada kata "memelihara". Sementara itu, pada terjemahan di atas didapati ada empat kata kerja yang perlu diperhatikan (Charis, 2016: 154) yaitu: dengarlah (shema), mempelajari (lamad), memerhatikan (shamar), dan melaksanakannya (asah). Kata yang pertama adalah "shema" diterjemahkan dengan "dengarlah" yang maknanya adalah perintah untuk ditaati. Kata yang kedua adalah "lamad" diterjemahkan dengan "belajar/mengajar". Seorang gembala di Israel membawa tongkat yang dipakai untuk mengarahkan dan mengendalikan domba. Kata Ibrani untuk tongkat adalah "lamed" yang berasal dari kata "lamad". Kata "lamed" mempunyai makna mengarahkan, belajar melalui pengarahan. Karena itu, kata "lamad" mempunyai makna belajar melalui pengarahan dan mengajar/memberi arahan. Jadi, dalam Ulangan 5:1 itu tersirat bahwa Israel diperintahkan belajar hukum Allah melalui pengarahan, serta Israel diperintahkan untuk mengajarkannya kepada anak-anak (Charis, 2016: 154).

Kata yang ketiga adalah "shamar" yang berarti menjaga, King James Vesion menerjemahkannya dengan keep/memelihara. Kata "shamar" juga berasal dari kehidupan gembala yang adakalanya harus bermalam di padang yang tidak ada penghuninya. Untuk melindungi domba-dombanya, gembala membuat pagar dari semak berduri yang berfungsi menjaga domba dari bahaya. Kata Ibrani untuk duri adalah "shamiyr". Kata "shamar" berasal dari kata "shamiyr" itu. Jadi, "shamar" mempunyai makna menjaga, melindungi. Hal ini berarti bahwa umat Israel harus melindungi ketetapan dan hukum Allah dari penyembahan berhala dan budaya asing lainnya. Kata yang keempat adalah "asah" yang berarti melakukan tindakan (Charis, 2016: 154).

Melalui Ulangan 5:1 ini dapat disimpulkan sebagai berikut: Kesatu, orang Israel harus mempelajari ketetapan/hukum Allah dan mengajarkannya kepada anak-anak. Demikian juga orang tua Kristen sekarang pun harus mempelajari ketetapan atau hukum Allah dan mengajarkannya kepada anak-anak dengan memohon pertolongan Roh kudus. Kedua, umat Israel harus melindungi ketetapan/hukum Allah dan menjaganya agar tidak tercemari oleh pengaruh asing. Demikian juga orang tua Kristen sekarang pun harus melindungi ketetapan/firman Tuhan yang telah diajarkan kepada anak-anak dan menjaganya dari pengaruh negatif/buruk/menyesatkan (Charis, 2016:157). Ketiga, Israel harus menerapkan hukum/ketetapan Allah dan melaksanakannya dalam kehidupan seharihari. Demikian juga orang tua Kristen sekarang pun harus mengajarkan firman Tuhan kepada anak-anak, bukan hanya melalui pengarahan, namun juga melalui 
keteladanan/praktek hidup orang tua sehari-hari. Melalui orang tualah anak belajar hidup, yaitu meniru, menyerap nilai-nilai, dan mempraktekkannya (Charis, 2016:160).

\section{Konteks Jauh}

Konteks jauh yang berhubungan dengan Shema Israel Ulangan 6:4-9 Adalah Ulangan 11. Dalam penguraian pengajaran yang disampaikan Musa di Ulangan 11 ini, Musa mengawali dengan menyampaikan tentang pentingnya perintah untuk mengasihi Tuhan (Ul. 11:1). Di sana Musa mengatakan: "Haruslah engkau mengasihi Tuhan, Allahmu, dan melakukan dengan setia kewajibanmu terhadap Dia dengan senantiasa berpegang pada segala ketetapan-Nya, peraturan-Nya dan perintah-Nya (APHB, 2011: 294). Wycliffe dalam "The Wycliffe Bible Commentary" mengatakan bahwa sesudah Musa mengatakan tentang "kamu tahu sekarang" (ay. 2), terdapat sebuah keterangan sisipan yang mencatat bahwa panggilan untuk mengambil keputusan terhadap perjanjian itu tidak diarahkan kepada angkatan yang lahir di padang gurun, tetapi diarahkan kepada umat yang telah lahir di Mesir dan menyaksikan tindakan-tindakan penghakiman Tuhan yang perkasa di masa lalu (ay. 7). Obyek yang dimaksud pada frasa "kamu tahu sekarang" adalah hajaran Tuhan dan kebesaran-Nya. Israel telah menerima disiplin untuk menghormati Tuhan selaku Hakim melalui pengalaman penghakiman-Nya atas musuh-musuh Israel (ay. 2-4) dan umat Israel sendiri (ay. 5-6). Dengan demikian Israel dapat mengetahui bahwa hukuman-Nya itu mahakuasa sehingga orang yang paling perkasa di bumi tidak bisa mencegahnya, dan hukuman-Nya adil tanpa pandang bulu sehingga bangsa perjanjian-Nya pun tidak berani memanfaatkan kedudukan khusus sebagai bangsa pilihan. Kemudian Musa meyampaikan alasan tentang pentingnya umat Israel untuk taat (ay. 8-9), yaitu supaya umat Israel menjadi kuat untuk memasuki serta menduduki negeri perjanjian dan supaya lanjut umur di tanah perjanjian itu. Wycliffe mengatakan tentang hubungan di antara usaha Israel menduduki negeri itu dengan kesetiaan (Harrison, 2014: 467).

Kesinambungan kesejahteraan Israel selama tinggal di negeri anugerah Allah, seperti halnya kesinambungan kesejahteraan Adam di firdaus yang asli, yaitu bahwa kesinambungan kesejahteraan itu tergantung pada kesinambungan ketaatan kepada Tuhan (Pfeiffer dan Harrison, 2014: 451). Berbeda dengan Mesir yang memiliki pertanian dengan irigasi, kemakmuran Kanaan tergantung langsung pada berkat Allah (ay. 11-12) sehingga dalam situasi itu hukuman Allah yang adil terhadap perilaku Israel akan ditunjukkan (ay. 13-17; Pfeiffer dan Harrison, 2014: 468).

Selanjutnya Musa mengatakan bahwa jika umat Israel dengan sungguh-sungguh mendengarkan perintah Tuhan yang disampaikan Musa, yaitu untuk mengasihi Tuhan dan beribadah kepada-Nya dengan segenap hati, jiwa, dan kekuatan, maka Tuhan akan memberikan hujan. Ini memberi pesan bahwa keadaan alam akan menjadi tolok ukur yang baik tentang hubungan Israel dengan Tuhan. Oleh sebab itu, Israel harus senantiasa waspada terhadap bahaya-bahaya rohani dari kelimpahan materi dan penyembahan berhala (ay. 13-17). Pada ayat 18 Musa mengatakan kembali bahwa umat harus menaruh perkataan-perkataan firman yang disampaikannya itu dalam hati dan 
jiwa, sebagai tanda pada tangan dan lambang di dahi. Ini memberi pesan bahwa kesetiaan dari angkatan ke angkatan akan menghasilkan kekalnya kepemilikan Israel atas negeri yang dijanjikan, selama ada langit di atas bumi (ay. 21), yang dengan kata lain adalah untuk selama-lamanya. Demikian juga sebaliknya, ketidaksetiaan umat pasti membawa pada berakhirnya kepemilikan. Hal ini seperti yang dinyatakan juga dalam Ulangan 6:6-9. Untuk Ulangan 11:22-23, pesan yang terkandung di dalamnya yang Musa sedang tekankan adalah bahwa keberhasilan dalam melaksanakan penaklukan yang telah ditetapkan (ay. 23-25) itu bukan tergantung pada keperkasaan pasukan, namun tergantung pada komitmen rohani. Dipenuhinya hukum yang terutama, akan mendatangkan berkat yaitu warisan berupa negeri yang dijanjikan hingga ke batas-batas luarnya, dari batas selatan yaitu padang gurun semenanjung Sinai, sampai batas utara yaitu pegunungan Libanon. Dari batas sebelah timur yaitu Sungai Efrat, sampai batas sebelah barat yaitu laut Mediterania (ay. 24), (Pfeiffer dan Harrison, 2014:468).

Jadi, berdasarkan uraian di atas dapat disimpulkan bahwa keterkaitan pesan dalam Ulangan 6:4-9 dengan konteks sebelum dan sesudahnya adalah sebagai berikut:

Kesatu, pada konteks ayat sebelumnya (U1. 5) pesan yang ditekankan adalah mengenai ketidaksetiaan dan ketidaktaatan "generasi orang tua dahulu" yang keluar dari tanah Mesir terhadap perjanjian dengan Tuhan, sehingga "generasi orang tua dahulu" ini mati di padang gurun dalam perjalanan menuju negeri perjanjian.

Kedua, pada konteks Ulangan 6, pesan yang ditekankan adalah Musa menguraikan kembali pengajaran, perintah, dan perjanjian Tuhan kepada umat Israel generasi kedua ("generasi orang tua kini”) yang lahir di padang gurun dalam perjalanan menuju negeri perjanjian, supaya memenuhi/melaksanakan mandat shema, yaitu "generasi orang tua kini" tersebut mempraktekkan hidup dalam ketaatan, iman, kasih, dan kesetiaan kepada Tuhan, dan selanjutnya mengajarkannya kepada anak-anak di tengah keluarga, supaya kepemilikan akan negeri perjanjian dan berkat-berkat Tuhan berlangsung selama-lamanya (selama ada langit di atas bumi).

Ketiga, pada konteks ayat sesudahnya (Ul. 11), pesan yang ditekankan oleh Musa adalah maksud, tujuan, atau alasan perlunya/pentingnya "generasi orang tua kini" tersebut untuk taat, mengasihi dan setia hanya kepada Tuhan saja.

\section{Tafsiran}

Peristiwa umat Israel berpasangan dengan Baal-Peor yang terjadi ketika umat Israel berada di Sitim, dataran Moab sehingga menewaskan dua puluh empat ribu orang (Bil. 25:1-9), serta mengakibatkan umat Israel masih harus mengalami hidup dalam pengembaraan di padang gurun selama tiga puluh delapan tahun lagi, telah menjadi pelajaran dan peringatan berharga bagi Musa ketika memimpin umat Israel hendak memasuki dan menduduki tanah perjanjian/tanah Kanaan. Sehingga setelah pengembaraan tiga puluh delapan tahun itu, atau yang merupakan tahun ke empat puluh dalam seluruh perjalanan di padang gurun, umat Israel tiba kembali di Moab, dengan tanah Kanaan/tanah perjanjian ada di hadapan umat Israel, maka di tanah Moab itulah 
Allah menyatakan kembali Hukum Allah kepada umat Israel, melalui Musa yang menguraikan Hukum itu (U1. 1:5; Park, 2011: 243-244).

Kata "menguraikan" dalam ayat ini dalam bahasa Ibraninya adalah " $b a$ 'ar". Kata kerja yang digunakan adalah berbentuk piel, perfect tense (selesai), sehingga memiliki makna "menjelaskan dengan sangat terperinci" atau "mengukir dengan jelas". Ini juga menunjukkan bahwa Musa tidak memberikan Hukum Taurat yang baru, tetapi Musa menjelaskan dengan teliti Hukum Taurat yang telah diberikan itu agar terukir di hati umat Israel. Di samping itu, Musa tidak hanya menguraikan hukum Allah saja, tetapi di dataran Moab itu, Musa juga memperingatkan bahwa Tuhan telah memunahkan umat Israel yang berpasangan dengan Baal-Peor ketika berada di Sitim yang adalah wilayah Moab, tetapi menyelamatkan dan membawa masuk ke tanah perjanjian, umat Israel yang berpaut pada Tuhan (Ul. 4:3-4). Kata "berpaut" (Ibr. dabaq) artinya "memegang erat-erat", "menempel", atau "menjadi satu dengan erat", sehingga dengan demikian dapat memasuki tanah perjanjian (Park, 2011: 243-244).

Pelajaran khusus yang perlu diperhatikan adalah bahwa di dataran Moab yang menjadi perkemahan terakhir, tepat sebelum umat Israel masuk Kanaan, hal utama yang ditekankan di sana adalah pentingnya pengajaran firman Tuhan, yaitu menjelaskan dan mengukirkan firman Tuhan itu dengan sangat terperinci, serta pentingnya umat Israel agar berpaut kepada Tuhan, yaitu memegang erat-erat, menempel, atau menjadi satu dan erat dengan Tuhan. Sehingga dengan demikan, umat Israel memenuhi apa yang terkandung dalam mandat "shema", yaitu mendengar, mengingat, mentaati, mematuhi, tunduk, memahami, memperhatikan, meresponi, melakukan, apa yang menjadi ketetapan, perintah, dan kehendak Tuhan, yaitu Allah Israel, dan tidak mengikuti ilahilah lain, sebaliknya harus mencintai, atau loyal/ setia hanya kepada TUHAN, Allah Israel. Selanjutnya, Musa menujukan dan memberikan mandat "shema" itu kepada para bapa (Ul. 4:9 dan U1. 6:7-9). Demikian juga di dalam Ulangan 6:7-9, Musa kembali menegaskan dan menekankan bahwa mandat "shema" itu memang ditujukan dan diserahkan kepada para bapa sebagai pemegang mandat dan yang mewariskan keimanan dalam satu keluarga (Park, 2011:245). Hal senada dikemukakan oleh Daeli dan Nainggolan bahwa dalam konteks rumah tangga pendidikan / pengasuhan ditangani oleh ayah ibunya (Ul. 6:4-9). Dalam hal itu, sikap yang tepat bagi zaman ini adalah iman anak dibentuk dalam konteks keluarga, yaitu diinjili dan dibina oleh orang tuanya sendiri (2020:56).

Dari studi eksposisi berdasarkan Ulangan 6:4-9 di atas, maka penulis menarik kesimpulan pembahasan di sini adalah mengenai relevansi diantara kesenjangan pola asuh pada orang tua dahulu, dampak dari kesenjangan orang tua dahulu terhadap orang tua kini, faktor yang menjadi penyebabnya, serta pola pengasuhan/pengajaran berdasarkan Ulangan 6:4-9 adalah sebagai berikut: 


\begin{tabular}{|c|c|c|c|}
\hline $\begin{array}{l}\text { Kesenjangan } \\
\text { atau kegagalan } \\
\text { Pengasuhan } \\
\text { Orang tua } \\
\text { dahulu }\end{array}$ & $\begin{array}{l}\text { Dampaknya Bagi } \\
\text { Orang tua Kini }\end{array}$ & $\begin{array}{l}\text { Faktor Penyebab } \\
\text { Terjadinya } \\
\text { Kesenjangan }\end{array}$ & $\begin{array}{l}\text { Pola Pengasuhan } \\
\text { Ulangan 6:4-9 }\end{array}$ \\
\hline $\begin{array}{l}\text { 1.Kesenjangan } \\
\text { Peran }\end{array}$ & $\begin{array}{l}\text { Penyimpangan } \\
\text { perilaku pada } \\
\text { anak } \\
\text { ( } 85 \% \\
\text { penyimpangan } \\
\text { terjadi karena } \\
\text { ketiadaan } \\
\text { bapa/ayah) }\end{array}$ & $\begin{array}{l}\text { Budaya penyerahan } \\
\text { pengasuhan anak } \\
\text { kepada pihak lain }\end{array}$ & $\begin{array}{l}\text { Prioritas } \\
\text { pengasuhan: } \\
\text { 1. Tuhan (Relasi } \\
\text { yang erat/intim) } \\
\text { 2. Keluarga } \\
\text { 3. Pekerjaan, } \\
\text { Pelayanan }\end{array}$ \\
\hline $\begin{array}{r}\text { 2.Kesenjang } \\
\text { pengajara }\end{array}$ & $\begin{array}{l}\text { Pengajaran dari } \\
\text { orang tua dahulu } \\
\text { tidak } \\
\text { tersampaikan } \\
\text { kepada anak, } \\
\text { yang dikemudian } \\
\text { hari menjadi } \\
\text { orang tua }\end{array}$ & $\begin{array}{l}\text { Orang tua yang tidak } \\
\text { menyampaikan } \\
\text { pengajaran kepada } \\
\text { anak }\end{array}$ & $\begin{array}{l}\text { Firman Tuhan } \\
\text { adalah yang } \\
\text { menjadi otoritas } \\
\text { dalam pengasuhan } \\
\text { dan pengajaran } \\
\text { anak }\end{array}$ \\
\hline $\begin{array}{l}\text { 3. Kesenjangan } \\
\text { prioritas }\end{array}$ & $\begin{array}{l}\text { Terjadi berbagai } \\
\text { macam masalah } \\
\text { dalam keluarga }\end{array}$ & $\begin{array}{l}\text { Penataan prioritas } \\
\text { yang salah atau yang } \\
\text { tidak seharusnya, } \\
\text { mengabaikan hal } \\
\text { kerohanian, baik } \\
\text { kerohanian dirinya } \\
\text { sendiri maupun } \\
\text { kerohanian anak }\end{array}$ & $\begin{array}{l}\text { Orang tua lebih } \\
\text { dulu } \\
\text { mempraktekkan } \\
\text { hidup dalam kasih, } \\
\text { kesetiaan, ketaatan, } \\
\text { iman hanya kepada } \\
\text { Tuhan. }\end{array}$ \\
\hline $\begin{array}{l}\text { 4.Kesenjangan } \\
\text { perilaku }\end{array}$ & $\begin{array}{l}\text { Menerima } \\
\text { keteladanan yang } \\
\text { buruk dalam } \\
\text { pengasuhan }\end{array}$ & $\begin{array}{l}\text { Relasi orang tua } \\
\text { dengan anak yang } \\
\text { sudah rusak sejak } \\
\text { kecil }\end{array}$ & $\begin{array}{l}\text { Orang tua aktif } \\
\text { mengajarkan kasih, } \\
\text { kesetiaan, ketaatan, } \\
\text { iman kepada anak } \\
\text { secara berulang- } \\
\text { ulang }\end{array}$ \\
\hline $\begin{array}{l}\text { 5.Kesenjanga } \\
\text { ketidaktuntasan } \\
\text { pembentukan } \\
\text { kerohanian dan } \\
\text { kepribadian } \\
\text { anak } \\
\end{array}$ & $\begin{array}{l}\text { Di kemudian hari } \\
\text { anak tidak siap } \\
\text { menjadi orang tua }\end{array}$ & $\begin{array}{l}\text { Perilaku orang tua } \\
\text { yang cenderung } \\
\text { mengabaikan/tidak } \\
\text { menuntaskan tugas } \\
\text { pengasuhan anak }\end{array}$ & $\begin{array}{l}\text { Mempersiapkan, } \\
\text { melatih anak untuk } \\
\text { siap menjadi orang } \\
\text { tua }\end{array}$ \\
\hline $\begin{array}{l}\text { 6. Kesenjangan } \\
\text { ketidaksiapan } \\
\text { menjadi Orang } \\
\text { tua }\end{array}$ & $\begin{array}{l}\text { Karena tidak siap } \\
\text { jadi orang tua, } \\
\text { cara termudah } \\
\text { dalam } \\
\text { pengasuhan } \\
\text { adalah meniru } \\
\text { orang tua dahulu }\end{array}$ & $\begin{array}{l}\text { Mengadopsi/meniru } \\
\text { Pola pengasuhan } \\
\text { yang buruk dari } \\
\text { orang tua } \\
\text { sebelumnya }\end{array}$ & $\begin{array}{l}\text { Pengasuhan oleh } \\
\text { orang tua dengan } \\
\text { berpusat kepada } \\
\text { Tuhan }\end{array}$ \\
\hline
\end{tabular}




\section{SIMPULAN DAN SARAN}

Dari hasil penelitian yang dilakukan, penulis menyimpulkan bahwa hal yang bisa dilakukan orang tua masa kini untuk menjembatani kesenjangan yang terjadi pada pola asuh orang tua dahulu, sehingga "warisan" pola asuh yang tidak baik itu tidak diteruskan kepada generasi selanjutnya, maka orang tua masa kini harus hidup dengan komitmen rohani yaitu mengasihi, setia, iman, dan taat hanya kepada Tuhan saja. Karena, ketika orang tua hidup dengan berpaut, melekat, erat dengan Tuhan, maka orang tua dapat menerima dan melaksanakan dengan segera mandat Tuhan untuk mengasuh dan mendidik anak, orang tua juga dapat menempatkan dan menjalankan prioritas rohani sebagai yang terutama dan pertama dalam mengasuh dan mendidik anak, yaitu memenuhi kebutuhan akan pertumbuhan dan kesejahteraan rohani anakanak.

Hal ini terlihat melalui beberapa pengamatan sebagai berikut: Kesatu, Ulangan 6:4-9 berisi mandat/perintah Tuhan kepada orang tua (dimulai dari ayah/bapa) untuk mengasuh dan mendidik anak sebagai bentuk/cara orang tua mengasihi dan taat kepada Tuhan. Kedua, Ulangan 6:4-9 menekankan keutamaan prioritas pada pemenuhan kebutuhan akan pertumbuhan dan kesejahteraan rohani anak-anakyang harus dipenuhi oleh orang tua. Ketiga, Tuhan memandang pola asuh adalah hal penting dalam kehidupan keluarga. Tuhan sendiri memberi teladan melalui Yesus Kristus yang dalam kemanusiaannya tetap berada dalam asuhan orang tuanya. Keempat, ada hubungan yang kuat antara komitmen rohani orang tua dengan berkat-berkat Tuhan atas keluarga. Kesinambungan kesejahteraan keluarga, adalah tergantung pada ketaatan dan komitmen rohani orang tua.

Karena itu, berdasarkan kitab Ulangan 6:4-9, maka pola asuh yang diajarkan (direkomendasikan) sebaiknya adalah: Kesatu, dengarlah (Ul. 6:4), artinya orang tua harus lebih dulu mempraktekkan hidup dengan ketaatan dan iman hanya kepadaTuhan saja di dalam mengasuh dan mendidik anak. Kedua, kasihilah (U1. 6:5), artinya orang tua lebih dulu mempraktekkan hidup yang mengasihi dan setia kepada Tuhan dengan sungguh-sungguh. Ketiga, memperhatikan (Ul. 6:6), artinya orang tua harus meletakkan sesuatu yang terpenting yaitu firman Tuhan, di tempat yang terpenting yaitu di hatinya. Dengan kata lain, orang tua hidup dalam komitmen rohani dengan Tuhan, Keempat, mengajar/mengasah/melatih (Ul. 6:7), artinya setelah orang tua lebih dulu mempraktekkan dan memenuhi komitmen rohani dengan Tuhan, maka selanjutnya orang tua mulai memerankan fungsi dan panggilannya sebagai pengasuh dan pendidik yang utama dan pertama bagi anak-anak dengan segera, yaitu yang terutama dan pertama adalah mengajar, mengasah/melatih, dan meneladankan hidup dengan komitmen rohani itu kepada anak-anak (pengasuhan dan pendidikan yang berpusat kepada Tuhan). Kelima, mengikatkan dan menuliskan (Ul. 6:8-9), artinya orang tua harus menjadikan firman Tuhan adalah otoritas di seluruh aspek kehidupan dan di setiap keputusan-keputusan. Sehingga dengan demikian, menjadikan hidup setiap keluarga itu berbeda dengan kehidupan para penyembah berhala yang ada di sekelilingnya. Jadi, 
pemilihan Ulangan 6:4-9 sebagai dasar untuk melakukan studi eksposisi tentang pola asuh orang tua terhadap anak dan relevansinya bagi orang tua masa kini, dimana dalam shema Ulangan 6:4-9 itu terkandung pesan adanya prioritas pada pemenuhan kebutuhan rohani yang perlu dipenuhi oleh orang tua sebagai penerima mandat dari Tuhan untuk mengasuh dan mengajar anak, dengan demikian telah terpenuhi.

\section{DAFTAR PUSTAKA}

Alkitab Sabda, "Ulangan 5:1", Sabda Web, https://www.sabda.org/sabdaweb/bible/chapter/?b=5\&c=5\&version=nkjv\&lang =indonesi a\&theme=clearsky, Diakses pada tanggal 17 Oktober 2020 pukul 21.30 WIB.

Alkitab Penuntun Hidup Berkelimpahan (2010). Malang: Gandum Mas.

Charis, Edwin (2016). Smart Parenting. Yogyakarta: Penerbit Andi.

Daeli Adventrianis, Nainggolan, Alon Mandimpu (2020). Persepsi Jean Charlier De Gerson dan Tuhan Yesus Kristus Mengenai Pendidikan Agama Kristen Anak. Montessori: Jurnal Pendidikan Kristen Anak Usia Dini. Vol. 1 No. 2, h. 45-57. https://ejournal-iakn-manado.ac.id/index.php/montessori/article/view/496/360.

Heath, Warren Stanley (2016). Keluarga Kristen: Antisipasi Pengaruh Pendidikan Global dalam Keluarga. Bandung: Biji Sesawi.

Nainggolan, Alon Mandimpu, Labobar Feni Yuni (2021). Menggagas Penggunaan Benih dalam Perayaan Paskah: Analisis Biblikal Yohanes 12:20-26. Epigraphe: Jurnal Teologi dan Pelayanan Kristiani. Vol. 5 No. 1, h, 113-125. http://www.stttorsina.ac.id/jurnal/index.php/epigraphe/article/view/239. http://dx.doi.org/10.33991/epigraphe.v5i1.239.

Prabowo, Wawan H. (2017)“Peran Ayah Semakin Pudar, Proses Identifikasi Diri Anak Bisa Terganggu.” Kompas. November 2017.

Pfeiffer, Charles F dan Everett F. Harrison (2004). Tafsiran Alkitab Wycliffe. Malang: Gandum Mas.

Park, Abraham (2011). Pertemuan Yang Terlupakan Dilihat dari Sudut Pandang Penyelenggaraan Sejarah Penebusan. Jakarta: PT. Gramedia Widiasarana Indonesia.

Thomas, Gary (2017). Sacred Parenting: Tanggung Jawab Mengasuh Anak Membentuk Hati Para Orangtua. Diterjemahkan oleh Ellen Hanafi. Yogyakarta: PT. Gloria Usaha Mulia. 
Wijanarko, Jarot (2000). Pemulihan Orangtua Anak. Jakarta: Suara Pemulihan.

Wijanarko, Jarot (2016). Ayah Ibu Baik. Jakarta: Keluarga Indonesia Bahagia.

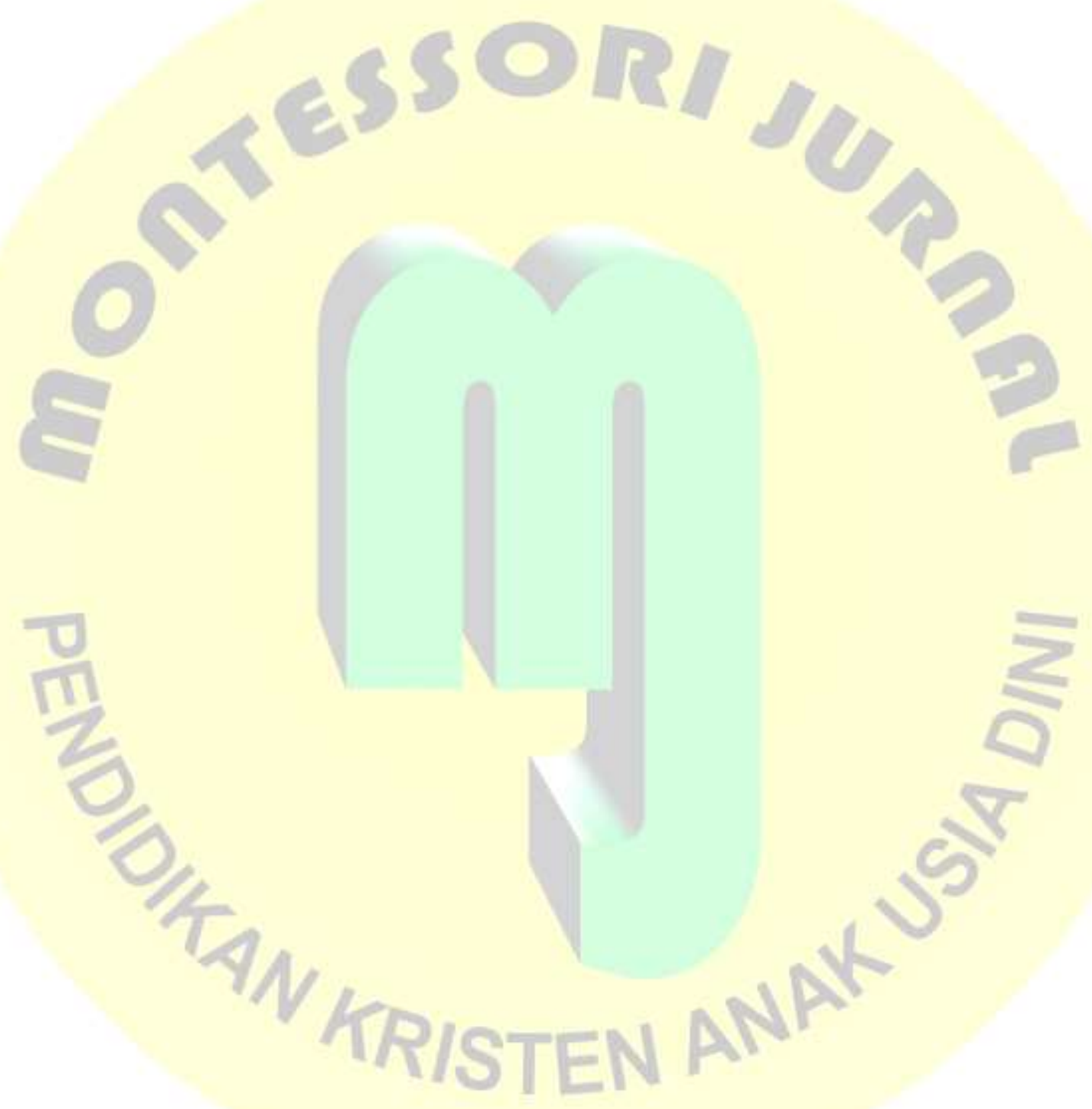

